\title{
Corporate Restructuring under the EMCA
}

\author{
by
}

\author{
Christoph Teichmann*
}

The European Model Company Act (EMCA) is designed as a free-standing company statute that can be enacted by EU Member States or by states outside the European Union in its entirety or in parts. Based on this intention, Chapter 13 of the EMCA offers a wide range of corporate restructuring operations. It takes into account the traditions of the EU Member States as well as EU secondary law and the relevant judgments of the European Court of Justice. Since cross-border operations are part of the European freedom of establishment and require a reliable framework, the EMCA does not only regulate domestic mergers and divisions but also cross-border mergers and divisions as well as the cross-border conversion of a company. The article outlines the content of Chapter 13 of the EMCA and the basic principles along the line of which corporate restructuring procedures are arranged in the EMCA.

Table of Contents

ECFR 2016, 277-300

I. Corporate restructuring as a means of adapting to the market . . . . . . . 277

1. Economic motives and stakeholder interests involved . . . . . . . . . 277

2. The function of the European Model Company Act (EMCA) . . . . . 279

II. Different forms of corporate restructuring $\ldots \ldots \ldots \ldots \ldots$. . . . . . . . 279

1. What is "corporate restructuring"? . . . . . . . . . . . . . . . 279

2. European secondary law on corporate restructuring . . . . . . . . 280

3. The different types of restructuring under the national law of EU Mem-

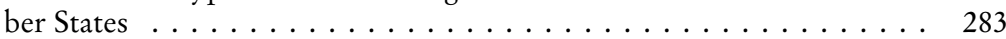

III. The EMCA approach . . . . . . . . . . . . . . . . . . . . 286

1. Outline of the content covered by Chapter $13 \ldots \ldots \ldots \ldots \ldots . \ldots 286$

2. EMCA as a "one law model" . . . . . . . . . . . . . . . . . . . . 288

3. Cross-border restructuring . . . . . . . . . . . . . . . . . . . . 290

4. Basic principles of corporate restructuring . . . . . . . . . . . . . 293

IV. Conclusion . . . . . . . . . . . . . . . . . . . . . . . . . . . . . . . 299

* Prof. Dr., University of Wuerzburg, Germany. 


\section{Corporate restructuring as a means of adapting to the market}

\section{Economic motives and stakeholder interests involved}

The company is a legal person which is used by its owners as a tool for doing business. Its shape and activity are designed according to the economic needs and the overall strategy of the owners. Once in a while, the business strategy or the external economic circumstances may change in a way that requires a new design of the corporate structure. Restructuring may also be seen as a means to rescue a company in financial difficulties. ${ }^{1}$ This article, however, approaches the issue of corporate restructuring on a more general level, since the various ways to restructure a company are not exclusively designed for situations of financial distress.

A restructuring may take place in a situation where the management and the shareholders come to the conclusion that the initially chosen company form is no longer suitable for their business activity, for instance, if a private company decides to go public. Restructuring may also serve as a means of expanding the business, e.g. when another business activity is commenced or another company acquired. ${ }^{2}$ In the latter case, the acquired company may continue to exist as a subsidiary of the acquiring company. But the existence of two legal persons creates costs and therefore a merger of the two companies may be considered. ${ }^{3}$ The reverse structural change is possible, too. A company which wants to give up parts of its business may either sell the assets dedicated to the particular business activity or execute a corporate division thereby creating a new company which will continue the business split off from the initial company.

Restructuring may affect the company as a legal person and its assets. Hence, the interests of stakeholders, such as shareholders, creditors and, as the case may be, also of employees, will have to be taken into account. Restructurings therefore require a specific legal framework balancing the interests involved in the corporate operation. The decision to merge or to divide a company will, in most cases, be prepared by the management organs and will require subsequent approval by the shareholders. Since mergers and divisions involve a transfer of assets, creditors' interests come into play. They may be protected by offering them a right to approve or to block the structural change. Another way to protect creditors consists in offering them particular securities if and

1 See e.g. B. Hannigan, Company Law, 3rd edition, 2012, p. 561 (No. 22-1).

2 B. Hannigan (above fn. 1), p. 680 (No. 26-2 to 26-3).

3 The merger is only rarely used in the UK (see Gower and Davies' Principles of Modern Company Law, 9th edition, 2012, p. 1104 (No. 29-1) and B. Hannigan (above fn. 1), p. 684 (No. 26-11)). It is, however, very common in Germany either as a post-acquisition transaction or as a means to simplify the internal structure of a group of companies. 
insofar as their legitimate expectation that their claims will be satisfied might be reduced after assets have been transferred from one company to another.

\section{The function of the European Model Company Act (EMCA)}

It follows that corporate restructuring is, on the one hand, a useful means to adapt company structures to new circumstances but that, on the other hand, a reliable legal framework taking into account the interests of the affected stakeholders is needed. National company law systems usually, in one way or another, offer the possibility to execute corporate restructuring. The European Model Company Act (EMCA), too, offers a legal framework for different ways of corporate restructuring.

The EMCA is designed as a free-standing company statute that can be enacted in its entirety or in parts. ${ }^{4}$ It has been elaborated by an independent group of academics and practitioners from more than 20 EU Member States, referred to in this article as the "EMCA group". ${ }^{5}$ In this way, the EMCA may be useful for EU Member States as a benchmark when reforming their company law systems; it can also be used as a tool box by states from outside the EU which want to align their legal system to EU standards. Chapter 13 on restructuring follows this general policy and offers a framework for restructuring which takes into account the national traditions of EU Member States as well as secondary EU law. In this way, it could also be useful for states outside the European Union who are interested in learning about the "state of the art" within the Union and who may wish to incorporate the chapter in its entirety or in parts into their own jurisdiction.

\section{Different forms of corporate restructuring}

\section{What is "corporate restructuring"?}

At first glance, it seems to be difficult to find a generally accepted definition of "corporate restructuring". The "structure" of the company can relate to different phenomena. It could mean the economic structure of the business, modelled, for instance, on the profit centre concept, or spread over numerous branches, domestically and abroad. In another sense the "structure" could

4 See EMCA, Introduction, No. 1.

5 The content of the EMCA and a list of the members participating in the EMCA group are retrievable at the project website run by the group's chairman Paul Krüger Andersen (http://law.au.dk/forskning/projekter/europeanmodelcompanyactemca/) and at the author's university website (www.jura.uni-wuerzburg.de/lehrstuehle/teichmann). 
relate to the basic features of the company which are established by company law and which usually do not change over the existence of the company, such as the characteristic of the company as a legal entity, the legal form of the company (private or public company) and the registered office of the company. Company law restructuring in the latter sense may even involve a change of the applicable company law ("cross-border restructuring"), which requires further attention when drafting the legal framework of the transaction.

From a company law perspective, corporate restructuring means an action whereby one or more of the above mentioned basic legal features of the company are changed: The identity of the company as a separate legal entity, the change of the legal form of the company or its applicable company law ("lex societatis"). When restricting corporate restructuring to transactions affecting the company law environment of the company as a legal entity, the following forms of corporate restructuring measures, as provided for by national law of the Member States, come into focus: merger, division and conversion - each of them either domestically or in a cross-border situation.

There are obvious interconnections between the legal and the economic point of view. In a cross-border context, a modification of the economic structure by establishing branches, agencies or other establishments abroad is an activity which is protected by the European freedom of establishment. ${ }^{6}$ Article 49 TFEU (Treaty on the Functioning of the European Union) places these economic structures on the same footing as the cross-border establishment of a subsidiary as a separate legal entity, since an establishment could mean the "setting-up of agencies, branches or subsidiaries". Only the last case, however, is a company law matter, whereas the simple establishment of a branch or agency does not affect the legal structure under company law.

\section{European secondary law on corporate restructuring}

\section{a) Domestic merger of public companies}

The European Economic Community, as early as 1978, started to harmonize the legal rules on corporate restructuring, first with a focus on domestic restructuring. The third company law directive on mergers $(78 / 855 / \mathrm{EEC})$ introduced the merger concept in the national law of all Member States while ensuring adequate protection of shareholders and creditors. ${ }^{7}$ The directive

6 See St. Grundmann, European Company Law, 2007, p. 487 et seq.

7 Third council directive of 9 October 1978 concerning mergers of public limited liability companies, OJEC, No L 295/36 of 20.10.1978, following several amendments, this direc- 
aims at harmonizing the legal rules for domestic mergers, in the sense of the merger of two public companies being governed by the applicable law of a particular European Member State. ${ }^{8}$ The directive does not introduce the possibility of a cross-border merger, this was left to another directive, which, however, was blocked for many years by the issue of employee co-determination. It was only in 2005 that the tenth company law directive closed this gap (see below $2 \mathrm{c}$ ). ${ }^{9}$

This restricted scope of application of the third directive (domestic mergers executed by public companies) raises the question of why the European legislator has taken action at all. European legislation in this area, however, can be justified by the fact that creditors and shareholders quite often have different nationalities and that they may have a legitimate expectation to be protected on a comparable level in all European Member States. ${ }^{10}$ In addition, secondary law wanted to increase legal certainty by limiting the number of cases in which invalidity of the merger can arise. The fact that the directive only applies to public companies can be explained by the assumption that cross-border shareholdings and internationally diverse creditors are more common in public companies than in private companies. Hence, the third directive is part of the general approach in European secondary law to focus on harmonizing the legal framework of public companies. The third directive followed the second directive on capital which, too, is only applicable to public companies. Notwithstanding this self-restriction of European law, Member States are free to introduce rules on the merger of private companies, which many Member States in fact did to complement the legal framework for mergers.

\section{b) Domestic division of public companies}

In 1982, the sixth company law directive concerning the division of public companies was enacted. ${ }^{11}$ Complementary to the third directive on mergers, it

tive has been recodified by directive 2011/35/EU, OJEU, No L 110/1 of 29. 4. 2011. For an account of the merger directive see E. Werlauff, EC Company Law, $2^{\text {nd }}$ edition, p. 566 et seq.

8 See Article 2 of Directive 2011/35/EU (above fn. 7): “[...] as regards companies governed by their national laws [...]".

9 Directive 2005/56/EC, 26 October 2005, OJ, 25.11. 2005, L 310/1.

10 See recital (4) of Directive 2011/35/EU (above fn. 7): “The protection of the interests of members and third parties requires that the laws of the Member States relating to mergers of public limited liability companies be coordinated...”.

11 Directive 82/891/EEC, OJEC, 31.12.1982, No L 378/47 leaves the decision to the Member States whether to introduce a procedure for the division of public companies. Article 1 simply states that where Member States permit divisions they shall subject those operations to the provisions of the directive. 
only covers public companies. Given the similarities between mergers and divisions, the main intention of the sixth directive was to avoid circumvention of the guarantees given with regard to mergers. ${ }^{12}$ It therefore offers the same safeguards for shareholders and creditors as the directive on mergers. Member States only have to implement the directive on divisions if they decide to permit public companies under their own jurisdiction to carry out division operations at all. ${ }^{13}$ Consequently, the directive does not force Member States to introduce a division procedure, but if they do so, they will have to comply with the sixth directive.

\section{c) Cross-border merger}

After many years of negotiation, the tenth company law directive on crossborder mergers was adopted in 2005. ${ }^{14}$ It allows for the merger of limited liability companies governed by the laws of different Member States. The reason why it took almost thirty years after adoption of the directive on domestic mergers to complete the cross-border merger directive lies in the different co-determination systems of the Member States. Only after a compromise had been reached in this respect by adoption of the directive on the involvement of employees in the European Company, ${ }^{15}$ that compromise consisting in a negotiation procedure - could be applied to the cross-border merger as well ${ }^{16}$.

The cross-border merger directive is applicable to all forms of limited liability companies (Art. 1 of the directive), provided that these forms may merge under the national law of the relevant Member State (Art. 4 (1) of the directive). This means that public companies are always covered, since the merger of public companies was introduced into the national legal systems by the third company law directive, whereas private companies may only merge cross-border insofar as the national law of the Member States concerned allows for mergers of private companies.

12 See 4th "Whereas" of directive 82/891/EEC.

13 See Article 1 of directive 82/891/EEC.

14 Directive 2005/56/EC, 26 October 2005, OJ, 25.11. 2005, L 310/1.

15 Directive 2001/86/EC, 8 October 2001, OJ, 10.11.2011, L 294/10.

16 See Article 16 cross-border merger directive, referring to the directive on the involvement of employees in the European Company. 
3. The different types of restructuring under the national law of EU Member States

\section{a) Merger}

Based on the third company law directive (see above 2 a), all EU Member States offer the possibility of restructuring by merger of two public companies. One of the companies involved will cease to exist as a result of the merger and its assets will thereby be transferred to the acquiring company which continues to exist. Many Member States have extended the scope of application of these rules to mergers involving private companies and other legal entities; some countries, like Germany, even allow the merger of partnerships. ${ }^{17}$

\section{b) Division}

The reverse transaction to the merger is the division. This procedure also seems to be offered by most of the Member States, even though there is no European obligation to introduce it on the national level..$^{18}$ In the course of the division, a company may be split into two companies thereby transferring its assets to the newly incorporated companies, based on a division plan which distributes the assets to the acquiring companies. The division may also take place as a transfer of the assets to several already existing companies. All in all, at least theoretically, the same variety of options, involving other legal entities and even partnerships, can be made available as with regard to mergers. ${ }^{19}$

\section{c) Conversion}

A third way of corporate restructuring is the change of the company form (conversion). In those Member States which draw a clear line between the private and the public company, the change from one form to another requires a formal transformation of the company. Once more, Germany may serve as an example. According to German company law doctrine, the private com-

17 Under $\$ 3$ (1) German Transformation Act (Umwandlungsgesetz) the chapter on mergers covers, inter alia, private and public companies, cooperative societies, partnerships and associations.

18 See above fn. 11.

19 See $\$ 124$ (1) German Transformation Act, defining the scope of application of the chapter on divisions by referring to $\$ 3(1)$, as mentioned above in fn. 17 . 
pany (Gesellschaft mit beschränkter Haftung) and the public company (Aktiengesellschaft) are different company forms. They are regulated in different acts (GmbH-Gesetz and Aktiengesetz respectively) with different requirements for incorporation and internal organization. ${ }^{20}$ The alteration of the company form - from private to public or vice versa - is regarded as a conversion and is subject to the conversion procedure as laid down in the German Act on Transformations (UmwG - Umwandlungsgesetz).

Member States which follow the "one company" model, such as the United Kingdom, consider the change from a private to a public company, or vice versa, to be a simple re-registration. ${ }^{21}$ Private and public companies are both subject to the Companies Act, the main difference being that the private company must not offer its securities to the public (see Sec. 755 UK Companies Act). ${ }^{22}$ When incorporating the company, the founders decide whether it should be "private" or "public". Any company which is not a public company in the sense of the Companies Act will automatically be a private company (see Sec. 4 UK Companies Act). In such a system, a company which started as private may re-register by an alteration of its articles and thereby may become a public company.

From a functional perspective, however, the differences between the "two companies" and the "one company" model should not be overestimated. The procedures of conversion, on the one hand (as in Germany), and reregistration on the other hand (as in the UK), are rather similar. They require a special resolution of the shareholders, an increase of the share capital to the amount required for public companies, a change of the company name and, finally, formal acknowledgement of the new company form by the registrar. ${ }^{23}$

\section{d) Takeover}

Whether the so-called "takeover", whereby one company acquires a number of shares in another company in order to achieve control in the latter company, ${ }^{24}$ is a structural change in the company law sense of the word seems

20 Just to give two examples: The minimum capital in the public company $(50,000)$ is higher than in the private company $(25,000)$; the establishment of a supervisory board is mandatory in public companies and optional in private companies.

21 See Gower and Davies (above fn. 3), p. 104-107 (No. 4-39 to 4-42), B. Hannigan (above fn. 1), p. 16-17 (No.1-52 to 1-54).

22 Gower and Davies (above fn. 3), p. 14-16 (No. 1-13 to 1-15); B. Hannigan (above fn. 1), p. 14 (No.1-42).

23 Compare Sections 90 to 96 UK Companies Act and $\$ \$ 238$ to 250 German UmwG.

24 As to the definition of takeover see Gower and Davies (above fn. 3), p. 1010 (No. 28-1), B. Hannigan (above fn. 1), p. 680 (No. 26-1). 
debatable. The acquisition of shares in the company, at first sight, does not affect the company law structure as such. The acquisition procedure, however, is intensely regulated, at least for listed companies. Some countries have included these rules in their Companies Act, such as the UK (see Chapter 28 $\mathrm{CA}$ ), others have enacted separate legal rules applying exclusively to listed companies (e.g. the German Takeover Act - Wp $\dot{U} G$ ). The takeover may therefore be regarded as a part of capital market law, even though it has some company law implications. For instance, the legal duties of the management board in the target company may change in the wake of a takeover bid to the effect that it must not discourage the takeover bid.

In a broader sense the takeover may be taken into account, because it is somewhat similar to a merger in its economic effects. The economic activities of two different companies may be combined by two alternative legal mechanisms: In the case of the takeover, one company acquires the majority of the shares in another company thereby gaining control over its economic policy. In the case of a merger, the acquired company ceases to exist, which reflects the same philosophy that the business of the two companies is continued under a common strategy. In both cases, the objective is a unitary enterprise with a centralized decision-making centre.$^{25}$ It is worth noting that some jurisdictions, like Germany, observe a high number of mergers, whereas in other Member States, like the UK, the merger procedure is practically unused, instead the purchase of shares is the preferred way to combine two businesses ${ }^{26}$. One possible explanation may be a different tax treatment; under German tax law the acquisition of a company by way of a merger avoids the disclosure of hidden reserves ${ }^{27}$.

\section{e) Scheme of arrangement}

In the UK and Ireland, there is a particular procedure which can also serve as a tool to carry out corporate restructuring, the scheme of arrangement. ${ }^{28} \mathrm{It}$ is used for takeover transactions as well as for restructuring companies coming close to insolvency, and there are many more possible applications. The scheme requires the consent of a qualified majority within the shareholders and within the creditors, whereby both groups may be divided into different classes, and finally has to be sanctioned by the court. The court will see that the statutory provisions have been complied with, that the classes were fairly

25 St. Grundmann (above fn. 6), p. 590 et seq.

26 B. Hannigan (above fn. 1), p. 32 (no. 2-30).

27 See $₫ 11$ Umwandlungssteuergesetz.

28 Gower and Davies (above fn. 3), p. 1105-1113 (No. 29-2 to 29-9), B. Hannigan (above fn. 1), p. 713-722 (No. 26-82 to 26-104). 
represented, that the majority is acting bona fide and not coercing the minority and that, finally, "the arrangement is such as an intelligent an honest man, a member of the class concerned and acting in respect of his interest, might reasonably approve." 29

\section{The EMCA approach}

\section{Outline of the content covered by Chapter 13}

Chapter 13 of the EMCA deals with the following forms of corporate restructuring:

- Takeover

- Scheme of arrangement

- Merger, domestically and cross-border

- Division, domestically and cross-border

- Cross-border conversion

a) Takeover

The operation of a takeover is not covered in a comprehensive way by the EMCA. It did not seem desirable to the EMCA group to include all the provisions regulating a takeover within the EMCA, since these rules are capital market rules and exceed the scope of company law. Chapter 13 restricts itself to setting out the board neutrality rule (Ch. 13, sec.1 EMCA), because this rule concerns the duties of the directors which is a core company law matter.

\section{b) Scheme of arrangement}

The EMCA group also discussed whether the scheme of arrangement should be included in Chapter 13. The scheme is a procedure which is widely used in Ireland and the UK. Its attractiveness is demonstrated by several cases, where companies incorporated under the law of other Member States tried to restructure their debts under English law in order to make use of the flexible

29 These safeguards are known as the "Buckley's test", see Gower and Davies (above fn. 3), p. 1112-1113 (No. 29-9), B. Hannigan (above fn. 1), p. 720 (No. 26-99). 
rules the scheme offers. ${ }^{30}$ One aspect which was attractive to these companies consists in the rule whereby a majority decision of the creditors will be binding even on opposing creditors. Hence, individual creditors might lose their claims against their will. This consequence seems to be in conflict with the rule of law principle, at least from the perspective of some continental jurisdictions. Irish and English lawyers, however, argue that misuse of the instrument can be excluded by the fact that the court has to sanction the scheme of arrangement.

The EMCA group therefore considered that the scheme of arrangement should be part of the EMCA since it might also be a useful tool for other jurisdictions. But the group stressed in its considerations that this is dependent on the question whether national judges are sufficiently qualified for taking the responsibility to reconcile potentially opposing interests amongst shareholders and creditors. Chapter 13 therefore outlines only the basic procedure of a scheme of arrangement (Ch. 13, sec. 2 to 4 EMCA). The reader should nevertheless be aware of the fact that this instrument is closely related to a particular legal culture.

\section{c) Merger and division}

As to mergers and divisions, which are extensively dealt with in Chapter 13, the EMCA group relied on an established procedure which can be extracted from several EU directives and the law of many Member States. The basic steps which are common to all these legal acts will be presented below. The chapter also covers cross-border mergers and divisions. Based on the tenth company law directive on cross-border mergers, EU law offers sufficient guidelines to include provisions not only on the cross-border merger but also on the cross-border division. As mentioned above, the procedures for mergers and divisions are in many respects similar to each other; this assumption also applies in a cross-border environment.

\section{d) Cross-border conversion}

In addition, the EMCA offers a procedure which is, so far, a "missing link" in European company law: the cross-border transfer of the seat or, in other words, the cross-border conversion. This transaction has been dealt with

30 One example is the case of the German company Rodenstock GmbH where the London High Court of Justice accepted jurisdiction to sanction a scheme of arrangement due to a choice of law clause in a senior debt agreement (Re Rodenstock GmbH [2011] EWHC 1104 (Ch), Neue Zeitschrift für Insolvenzrecht 2011, p. 557 et seq., International Insolvency Law Review 2011, p. 591 et seq.). 
by the European Court of Justice in its Vale case. There the court stated that companies governed by the law of a Member State, in general, should be allowed to convert into companies governed by the law of another Member State. ${ }^{31}$ This reasoning is based on the freedom of establishment (Articles 49 and 54 TFEU) and is not dependent on the existence of rules laid down in secondary EU law. ${ }^{32}$ But, as the court made clear, such rules for facilitating cross-border conversions would indeed be very useful. ${ }^{33}$ What is more, the European legislator already provides the legal framework for such a procedure in Art. 8 SE Regulation. The EMCA group therefore considered that the cross-border conversion is a necessary part of a modern company law framework and included the relevant provisions in Chapter 13.

\section{EMCA as a "one law model"}

\section{a) General approach}

The approach of the European Model Company Act is based on its general assumption that private and public companies are not strictly separated legal forms but rather two varieties of the "company". The EMCA is a "one law model" covering both the private and the public company. ${ }^{34}$ This is reflected in Chapter 1, Sec. 3 (3) EMCA: "Unless otherwise prescribed, this Act shall apply to private as well as public companies." Based on these assumptions, the re-incorporation of a private company as a public company is not part of the chapter on corporate restructurings but constitutes a simple amendment of the articles. $^{35}$

Like many national jurisdictions, ${ }^{36}$ the EMCA considers the restriction that the shares must not be offered to the public as the basic feature of a private company (Ch. 1, Sec. 3 (2) EMCA). ${ }^{37}$ The EMCA group was aware of the fact

31 Where Member States allow their national companies to convert into other national company forms (which in most or even all of the Member States is the case), they must not exclude companies governed by the law of other Member States from the conversion procedure (cf. ECJ Case C-378/10 (Vale) No.41).

32 ECJ Case C-378/10 (Vale) No. 38.

33 ECJ Case C-378/10 (Vale) No. 38.

34 See EMCA, Introduction Nos. 8 ("The EMCA covers both private and public companies") and 9 ("The EMCA uses a one law model").

35 See Ch. 4 Sec. 3 and Sec. 4 EMCA.

36 See above fn. 22.

37 Accordingly G. Bachmann/H. Eidenmüller/A. Engert/H. Fleischer/W. Schön, Regulating the Close Corporation, 2014, p. 7: "close corporation" means that the shares are not tradable. The same concept could be applied to a European Private Company (see 
that for private companies, as the case may be, in many circumstances more flexible rules than for public companies are justifiable. ${ }^{38}$ As a consequence, the regulatory framework for such a "closed company" will be relaxed, wherever this seems justifiable, taking into account the typical ownership structure of private companies with a small number of shareholders. ${ }^{39}$

\section{b) Different degrees of flexibility for private and public companies}

Based on the general intention to offer more flexibility to private companies, some provisions in the Chapter on corporate restructuring contain facilitated procedural rules for private companies. The shareholders of a private company may, for instance, dispense with the rule whereby the management organ has to draw up a merger plan (Ch. 13, Sec. 7 (2) EMCA) or a division plan (Ch. 13, Sec. 51 (2) EMCA). This exception does not apply, however, to the crossborder merger (and not to the cross-border division either), since the tenth directive does not provide for such an exception. ${ }^{40}$ Where the shareholders of a private company waived the requirement to have a merger (or division) plan, the main features of the corporate transaction have to be expressly addressed in the resolution of the general meeting, ${ }^{41}$ in addition, the shareholders have to ensure that identical resolutions will be passed in every private company which is involved in the transaction ${ }^{42}$.

The right to waive the directors' explanatory report by unanimous shareholder decision, however, applies to both public and private companies (Ch. 13, Sec. 8 (3) and Sec. 9 (5) EMCA). This is due to the fact that EU secondary law allows such an exception even for public companies in the case of domestic mergers (but not for the cross-border merger). ${ }^{43}$ The same principles apply to the

P. Hommelhoff/C. Teichmann in: H. Hirte/C. Teichmann (editors), The European Private Company - Societas Privata Europaea (SPE), 2013, p. 1, 2).

38 As a general approach see G. Bachmann/H. Eidenmüller/A. Engert/H. Fleischer/ W. Schön (above fn. 37), p. 15-16: mandatory law should be the exception, because within a small group of shareholders private autonomous arrangements are preferable. Also P. Hommelhoff/C. Teichmann (above fn. 37), p. 1, 7, regarding the proposal for a European Private Company.

39 See comments to Ch. 1, Sec. 3 EMCA.

40 See comments to Ch. 13, Sec. 22 EMCA.

41 These features are, amongst others, the names of the companies involved and the new articles of association to be applied after the operation comes into effect (see Ch. 13, Sec. 12 (6) EMCA for mergers, Ch. 13, Sec. 56 (6) EMCA for division).

42 See Ch. 13, Sec. 12 (7) EMCA for mergers, Ch. 13, Sec. 56 (7) EMCA for divisions.

43 Art. 9 (3) Directive 2011/35/EU, see comments to Ch. 13, Sec. 8 EMCA as well as comments to Ch. 13, Sec. 23 EMCA. 
domestic and the cross-border division. ${ }^{44}$ The option to waive the expert's examination is applicable, according to EU secondary law, ${ }^{45}$ to both domestic and cross-border mergers and the EMCA has taken the same view (Ch. 13, Sec. 9 (5) and Sec. 24 (5) EMCA). The same approach applies to the domestic and cross-border division (Ch. 13, Sec. 53 (5) and Sec. 68(5) EMCA). ${ }^{46}$

\section{Cross-border restructuring}

\section{a) Particular complexity of the transaction}

Cross-border restructuring of companies is of particular complexity. Since a company, in the words of the European Court of Justice, is "a creature of the law" ${ }^{\prime 7}$, its very existence depends on the application of the national legal system which granted legal personality to the particular company. In the case of cross-border restructuring, however, at least two different legal systems are involved. The cross-border transaction therefore requires the two legal systems to interoperate, it presupposes the consecutive application of two national laws. ${ }^{48}$ Theoretically, it is not impossible to find such cooperation accepted on a voluntary basis by one state or the other. But even if the legal systems are in general prepared to accept the cross-border transaction, the combination of two legal systems proves to be extremely cumbersome for the companies involved if there is no common legal framework for it. It can be assumed that companies usually try to avoid corporate restructuring without a clear legal framework combining the different legal systems which are involved. This has been proven by the study which has been commissioned by the European Commission in order to elaborate on the application of the cross-border merger directive. In this study, it could be established, not very surprisingly, that the number of cross-border mergers considerably increased after implementation of the cross-border merger directive in every EU Member State. ${ }^{49}$

44 See Ch. 13, Sec. 52 (3) EMCA as well as comments to Ch. 13, Sec. 67 EMCA.

45 Art. 10 (4) Directive 2011/35/EU, Art. 8 (4) Directive 2005/56/EC.

46 As to the domestic division see Art. 10 Directive 82/891/EEC).

47 See ECJ Case C-210/06 (Cartesio) No. 104 (referring to the earlier Daily Mail judgment where this expression was used for the first time).

48 ECJ Case C-378/10 (Vale) no 37; Marek Szydlo, The right of companies to cross-border conversion under the TFEU Rules on Freedom of Establishment, ECFR 2010, 414, 417 et seq.; Jesper Lau Hansen, The Vale Decision and the Court's Case law on the Nationality of Companies, ECFR 2013, 1, 10.

49 Bech-Bruun/Lexidale, Study on the application of the cross-border mergers directive, September 2013, page 6 . 
b) State of play in EU law

The European directive on cross-border mergers, so far, is the only instrument of EU secondary law regulating corporate restructuring in cross-border cases. For all other forms of cross-border restructuring, companies have to rely on European case law based on the freedom of establishment under Articles 49 and 54 TFEU. As a matter of principle, corporate restructuring is protected by the freedom of establishment: it constitutes an effective means of transforming companies within the framework of a single operation and allows them to pursue a particular activity in new forms and without interruption. ${ }^{50}$ Insofar as an operation is allowed for domestic purposes but not for cross-border operations, such national law establishes a difference in treatment between companies according to the internal or cross-border nature of the transaction which is likely to deter the exercise of the freedom of establishment and therefore amounts to a restriction within the meaning of Articles 49 and 54 TFEU. ${ }^{51}$ As a consequence, academic literature widely agrees that each corporate restructuring operation which is possible under national law should also be available for cross-border purposes. ${ }^{52}$ Chapter 13 of the EMCA takes this into account and offers both, domestic and cross-border operations, with regard to merger, division and conversion.

\section{c) Filling the gaps of cross-border operations}

Based on the above mentioned state of play in EU law, the EMCA group considered that a modern and comprehensive Company Act should cover both domestic and cross-border operations. Chapter 1, Sec. 13 EMCA expressly supports the principle of free movement within the European Union. Chapter 13 of the EMCA therefore offers a procedure for mergers and divisions, both domestically and cross-border, as well as a procedure for the cross-border conversion of a company. At first sight, this task seems to be more challenging than it really is. The major problems which a cross-border operation faces have already been solved on the European level when the tenth directive on the cross-border merger was adopted. In addition, the basic steps of the cross-border conversion

50 ECJ Case 411/03 (Sevic) No. 21 (regarding cross-border merger); confirmed by ECJ Case C-378/10 (Vale) No. 24 (regarding conversion).

51 ECJ Case 411/03 (Sevic) No. 22 (cross-border merger); ECJ Case C-378/10 (Vale) No. 36 (conversion).

52 M. Habersack/D. Verse, Europäisches Gesellschaftsrecht, 4th edition, 2011; M. Lutter/ W. Bayer/J. Schmidt, Europäisches Unternehmens- und Kapitalmarktrecht, 5th edition, 2012, p. 92-112; C. Teichmann, Europäisches Gesellschaftsrecht in: M. Gebauer/C. Teichmann (editors), Europäisches Privat- und Unternehmensrecht, Enzyklopädie Europarecht, Band 6, 2016, $\$ 6$ no. 59 (p. 518). 
are already addressed in the Regulation for the European Company. The EMCA group used these two acts of EU secondary law as a blueprint for the crossborder division and the cross-border conversion respectively.

One reason why cross-border operations require specific attention by the legislator is the need to coordinate the application of several legal systems. Since the cross-border operation requires the consecutive application of two different legal systems, the bridge between the two systems has to be built by substantive law on the procedure to be applied in such circumstances. An important mechanism to allow the step from one jurisdiction to another is the allocation of legal scrutiny between the competent authorities of the two jurisdictions. In the case of the cross-border merger, Article 10 of Directive 2005/56/EU requires each Member State to designate the court, notary or other authority competent to scrutinize the legality of the merger as regards that part of the procedure which concerns the merging company subject to its national law. This authority shall issue a certificate conclusively attesting to the proper completion of the pre-merger acts and formalities. ${ }^{53}$ The competent authority of the other jurisdiction which is involved may rely on this certificate which the company has to submit to the competent authority of the Member State where the merger will have to be finally registered for the acquiring company. EMCA applies the same procedure to each cross-border operation..$^{54} \mathrm{~A}$ pre-merger certificate will have to be issued in case of a crossborder merger (Ch. 13, Sec. 32 EMCA), a pre-transfer certificate in case of a cross-border conversion (Ch. 13, Sec. 45 EMCA) and a pre-division certificate in case of a cross-border division (Ch. 13, Sec. 76 EMCA).

\section{d) The connecting factor for the applicable company law}

One omission, however, has to be admitted. EMCA does not contain a chapter on international private law. There is no clear answer to the question which connecting factor determines the applicable company law. As anyone knows, there are two competing theories, the "incorporation theory" and the "real seat theory", with many varieties in between. ${ }^{55}$ European case law, based on

53 The same mechanism applies to the cross-border transfer of the registered office of a European Company (see Article 8 (8) Council Regulation (EC) 2157/2001 of 8 October 2001).

54 The function of the notary is not mentioned in EMCA, but this does not exclude states implementing the Model Act to make use of the notary. In such circumstances, a duplication of functions should be avoided (see introductory comments to Chapter 3 of the EMCA.

55 For an overview see G. Eckert, Internationales Gesellschaftsrecht, 2010, p. 29-41, and St. Rammeloo, Corporations in Private International Law, 2001, p. 9-25. 
EU freedom of establishment, is ambivalent in this respect, too. On the one hand, EU Member States have to recognize the legal capacity which a company, formed in accordance with the law of another Member State, enjoys under the law of its state of incorporation. ${ }^{56}$ On the other hand, a Member State has the right to determine the connecting factor for companies which are subject to his own jurisdiction; the Treaty "placed on the same footing" the different connecting factors: registered office, central administration and principal place of business. ${ }^{57}$

When talking about cross-border operations, therefore, the EMCA does not specify the connecting factor for the applicable company law. The Act restricts itself to substantive rules regulating the corporate operation as such. These substantive rules, however, only require a transfer of the registered office for a cross-border conversion (see Ch. 13, Sec. 36 EMCA) which implies the assumption that this transfer will lead to a change in the applicable company law. This assumption may, however, for two reasons require modifications when a state decides to implement the Model Act. First, the crossborder operation requires the combination of two legal systems (see above), which means that it depends on the other legal system involved whether the transfer of the registered office will be sufficient to change the applicable company law. Second, the EMCA itself only serves as a model which does not have to be implemented literally. A state interested in implementing the EMCA will be free to add, for instance, a provision whereby the transfer of the central administration is also required for the cross-border conversion to take legal effect.

\section{Basic principles of corporate restructuring}

Chapter 13 elaborates in a detailed way the different procedures of domestic and cross-border mergers and divisions as well as the cross-border conversion. For the purpose of this article, however, it seems to be sufficient to outline the basic principles which are common to all these procedures. ${ }^{58}$ In this respect, first of all, the interests of different stakeholders which require protection by the procedural rules on corporate restructurings must be mentioned (below a).

56 ECJ, C-208/00 (Überseering), 5 november 2002, no. 95.

57 ECJ, C-210/06 (Cartesio), 16 december 2008, no. 106.

58 These basic principles can also be found in EU secondary law as has been further elaborated by P. Hommelhoff and K. Riesenhuber, Strukturmaßnahmen, insbesondere Verschmelzung und Spaltung im Europäischen und deutschen Gesellschaftsrecht, in: St. Grundmann (editor), Systembildung und Systemlücken in Kerngebieten des Europäischen Privatrechts, Tübingen, 2000, p. 259-282. 
In order to protect stakeholders by offering them reliable information, the first step of any corporate restructuring consists in the management organ presenting a draft plan of the proposed transaction (below $b$ ). In addition, one or more experts have to examine the economic framework of the transaction, in particular the share exchange ratio in case of mergers and divisions (below c). This information is mainly directed to the shareholders, who will have to resolve on the transaction in a general meeting (below d). Creditors may use this information, too, and will receive additional protection if there is a relevant risk that their claims may be endangered in the course of the restructuring (below e).

\section{a) Relevant stakeholder interests involved in the operation}

The rationale for regulating corporate restructuring procedures is to a great extent driven by the fact that different stakeholders of the company, such as shareholders, creditors and, as the case may be, employees, need particular protection.

As to shareholders, they are first protected by a right to obtain sufficient information on the envisaged procedure consisting in a preliminary restructuring plan to be drafted by the management organ. In addition, corporate restructuring requires the approval of the general meeting of the shareholders with a qualified majority. In cases of a cross-border operation, dissenting minority shareholders should have a sell-out right in order to leave the company.

Creditors, as the case may be, must be protected against suffering losses as a result of the corporate restructuring. The first means of protecting creditors, and other third parties, consists in the publication of sufficient information regarding the envisaged corporate restructuring. In addition, EU secondary law on mergers and divisions obliges Member States to lay down an adequate system for protecting the interests of the creditors. EMCA, too, offers a solution in this respect.

With regard to employees, there is a special need to protect their interests in the case of cross-border restructuring. EU law in this area has to face the difficulty that the systems of employee involvement are rather different within the Member States. Nevertheless, EU secondary law tries to protect the rights of employees to information, consultation and co-determination by offering a negotiation procedure in the case of cross-border restructuring. Since the EMCA does not regulate any employee rights on being involved in the internal company decision-making process, it did not take a stand on the protection of such rights in the course of corporate restructuring. The issue of employee involvement is to such an extent closely linked to national traditions and 
cultures that it seemed to be impossible to offer a common "model" in this respect. ${ }^{59}$

\section{b) Restructuring plan and management report}

The procedures of corporate restructuring in Chapter 13 EMCA, as well as in national and European company law, are based on the assumption that the corporate operation requires thorough preparation by the management organs of the companies involved. Therefore, in all these cases, a plan has to be drawn up by the management organ stating the basic features of the envisaged operation.

See for example Ch. 13, Sec. 7 EMCA on the merger plan: The management organ must state, inter alia, the names of the merging companies, the share exchange ratio and the date from which the merger will be effective. In addition, the management organ has to explain, by a detailed written report, the legal and economic grounds for the transaction (Ch. 13, Sec. 8 EMCA). Later on, when the general meeting has to resolve on the transaction (Ch. 13, Sec. 12 EMCA), the merger plan will shape the content of the resolution, whereas the management report will be the additional information to the shareholders enabling them to judge whether the transaction is useful to them and to the company or not. In order to prepare the decision, the shareholders have the right to inspect the documents to be provided by the management organ (Ch. 13, Sec. 11 EMCA).

Comparable provisions exist for the division and the cross-border conversion. A division plan has to be drafted by the management organ (Ch. 13, Sec. 51, EMCA), the plan must be further explained in a directors' explanatory report (Ch. 13, Sec. 52 EMCA) and will have to be finally approved by the general meeting (Ch. 13, Sec. 56 EMCA). The cross-border conversion, too, has to be approved by the general meeting (Ch. 13, Sec. 41 EMCA). This decision will be prepared by a transfer plan (Ch. 13, Sec. 37 EMCA) and a management report (Ch. 13, Sec. 38 EMCA).

\section{c) Expert's examination}

In some cases of corporate restructuring the proposal of the management organ must be evaluated by experts. This is particularly relevant in the case of a merger, where the shares of the company being acquired will be exchanged for shares of the acquiring company. The new shares are economically backed 
by the assets of the company being acquired which, as an effect of the merger, will be automatically transferred to the acquiring company. ${ }^{60}$

The share exchange ratio is therefore based on a valuation of the assets of both companies involved and will be of crucial importance for the shareholders of both companies. The shareholders of the company being acquired want to make sure that the exchange ratio reflects the actual value of their shares which will cease to exist when the merger takes effect. But also the shareholders of the acquiring company are interested in a correct share exchange ratio because the value of their participation may be watered down if too many new shares are extended to the shareholders of the company being acquired.

The share exchange ratio is first presented in the draft terms of merger to be prepared by the management organ (Ch. 13, Sec. 7, Subs. 3 b EMCA). It will be further explained in the directors' explanatory report, including a description of any special valuation problems which might have arisen (Ch. 13, Sec. 8 , Subs. 1 EMCA). Finally, the expert's report will have to state, in particular, whether, in the expert's opinion, the share exchange ratio is fair and reasonable; it must also state whether the method or methods used to arrive at the share exchange ratio were adequate (Ch. 13, Sec. 9, Subs. 2 EMCA).

The same basic steps apply in the case of a division. This procedure means that a company will be wound up and thereby transfer its assets to more than one other company (Ch. 13, Sec. 49 EMCA). This procedure, too, implies an exchange of the shares and therefore a valuation of the assets being divided and attributed to two or more different companies. The division plan has to state the share exchange ratio (Ch. 13, Sec. 51, Subs. 3 b EMCA), the directors will have to explain it (Ch. 13, Sec. 52, Subs. 1 EMCA) and an expert's report will have to confirm and further explain the share exchange ratio (Ch. 13, Sec. 53 EMCA).

\section{d) General meeting and protection of minority sharebolders}

As a general principle, operations of corporate restructuring have to be approved by the general meeting of the shareholders (see Ch. 13, Sec. 12 EMCA for the merger, Ch. 13, Sec. 56 EMCA for the division and Ch. 13, Sec. 41 EMCA for the cross-border conversion). The approval requires a qualified majority. Chapter 13 of the EMCA generally applies a majority in number, representing two thirds in value, of each class of shareholders. This is based on EU secondary law ${ }^{61}$ and reflects the solution to be found in the national law of

60 As to the legal effects of the merger, see Chapter 13, Sec. 19 EMCA.

61 See Art. 7 Directive 2011/35/EU: at least 2/3 of the votes attached to the shares or to the subscribed capital represented. 
many Member States, even though some of them require higher majorities (for example, Germany: majority of three quarters of the subscribed capital represented at the meeting).

The protection of minority shareholders is basically effected by prior information (management report and expert's examination) and indirectly by the requirement of a qualified majority. The EMCA group considered that there was no need for additional protection of dissenting shareholders, since their economic interests are protected by the expert's examination. A sell-out right of dissenting shareholders is left to the articles of association (see Ch. 13, Sec. 17 EMCA for the merger and Ch. 13, Sec. 61 EMCA for the division).

A different solution applies in the case of a cross-border operation where the applicable company law changes. This is a change of the legal framework which the minority shareholder must not accept against his or her will. Minority shareholders who have opposed the operation in the general meeting therefore have a right to transfer their shares to the company in return for appropriate cash compensation (see Ch. 13, Sec. 30 EMCA for the crossborder merger, Ch. 13. Sec. 44 EMCA for the cross-border conversion, Ch. 13, Sec. 61 EMCA for the cross-border division). This solution can also be found in several EU Member States, such as Denmark, Germany, Italy and Spain. ${ }^{62}$

\section{e) Creditor protection}

The legal effect of the merger may affect the interests of creditors who have claims against one of the companies involved in the merger. The creditors of the company being acquired are confronted with the legal consequence that this company will cease to exist (see Ch. 13, Sec. 19 (2) (d) EMCA). As a legal effect of the merger, the assets and liabilities of the company being acquired will be transferred to the acquiring company (see Ch. 13, Sec. 19 (2) (a) EMCA). The claims of the creditors therefore will be backed by the same assets as before, but they will have to direct their claim to the acquiring company which may have its own creditors who also try to get hold of the assets of the acquiring company. Depending on the economic situation of the two companies (the company being acquired and the acquiring company), this situation may be either advantageous or detrimental for either the creditors of the one or of the other company.

EU secondary law, therefore, states that the laws of the Member States "must provide for an adequate system of protection of the interests of creditors of the 
merging companies". ${ }^{63}$ This shall apply at least to those creditors whose claims antedate the publication of the merger plan and have not fallen due at the time of such publication. Member States apply different systems of creditor protection in this respect. ${ }^{64}$ The same variety of national solutions applies in a cross-border context; this is one of the reasons why the study commissioned by the European Commission came to the conclusion that the tenth directive did not sufficiently harmonize the cross-border merger procedure. ${ }^{65}$

Art. 496 of the Polish Commercial Companies Code gives priority to the creditors of the particular company with regard to the assets of this company. This means, however, that the assets still have to be managed separately even after the merger took effect, in order to allow for separate satisfaction of the creditors. $\$ 22$ of the German Transformation Act grants the right to creditors to claim adequate guarantees if they can credibly demonstrate that due to the merger the satisfaction of their claim is at risk. In France, ${ }^{66}$ creditors may oppose the merger and ask the court for protection which could consist, inter alia, in the payment of the claim or in offering guarantees to the creditors; the opposition of the creditor may not, however, block the transaction as such.

The EMCA group was looking for a way to protect creditors under the following guidelines. Creditor protection should not create too much additional cost, it should not require the involvement of a court and it should not considerably delay the procedure. In this respect the solution of Danish and Swedish law seemed to be attractive. It relies on the examination by an expert who has to examine the value of the assets in order to assess the exchange ratio for the shares. Section 242 of the Danish Companies Act requires the expert to make a declaration as to whether the creditors of the company can be considered to be sufficiently protected after the merger. Chapter 13 of the EMCA follows the same approach. The expert has to issue a declaration as to whether the creditors of each of the merging companies can be considered to be sufficiently protected after the merger (Ch. 13, Sec. 9 (3) EMCA for domestic mergers). Creditors may only claim adequate securities if (1) the expert concludes that they will not be sufficiently protected after the merger, or if (2) the expert expressly concludes that there is a need for additional safeguards, or if (3) the expert's report has been waived by the shareholders (see Ch. 13, Sec. 13 EMCA). As an additional safeguard, the EMCA provides for civil liability of the expert for any loss or damage suffered by any creditor for reason of misconduct in the preparation of his or her statement (Ch. 13, Sec. 20 EMCA for domestic mergers, Ch. 13, Sec. 64 EMCA for domestic divisions).

63 Art. 13 Directive 2011/35/EU.

64 See the comments to Ch. 13, Sec. 13 EMCA.

65 Bech-Bruun/Lexidale (above fn. 49), p. 10.

66 Article L236-14 Code de commerce. 
Another advantage of the creditor protection system adopted by the EMCA becomes apparent in the cross-border environment. Whereas some of the national solutions which apply to domestic operations will have to be modified in a cross-border situation, ${ }^{67}$ the EMCA solution is an appropriate protection not only for the domestic but also for the cross-border operation (compare Ch. 13, Sec. 13 for domestic and Sec. 28 for cross-border mergers as well as Ch. 13, Sec. 64 for domestic and Sec. 78 for cross-border divisions).

The only exception to this rule is the cross-border conversion. The conversion procedure does not imply the examination by an expert, since the assets of the company are not affected. The company will continue to exist under the new applicable company law, its assets and liabilities will remain unchanged. Creditors, in regular cases, therefore do not need any particular protection. Ch. 13, Sec. 42 EMCA only takes care of exceptional cases where the creditors can credibly demonstrate that the conversion will affect the satisfaction of their claim.

\section{Conclusion}

Corporate restructuring is an important means to adapt the shape and activity of the company to changing environments in the market. A modern and comprehensive company law should offer a reliable framework to carry out operations for structural change like the merger and the division. It should also offer the possibility to carry out these operations cross-border, including the cross-border conversion from one jurisdiction to another.

Restructuring operations affect the interests of various stakeholders, in particular shareholders and creditors, but, as the case may be, also employees. The legal framework should offer both an efficient procedure for the company and sufficient safeguards for stakeholders. In European company law as well as in the national law of many EU member states, basic steps have evolved that apply to every restructuring operation: the establishment of a draft transaction plan, a management report, an expert's assessment and the approval of the general meeting with qualified majority.

The EMCA is building on these general principles and spelling them out for the domestic merger and the domestic division. It also closes existing gaps in EU secondary law by offering, next to the cross-border merger which is already harmonized on the European level, a procedure for the cross-border

67 This is the case, for instance, in Germany where different procedures of creditor protection apply in domestic mergers and cross-border mergers (see $\$ 22$ and $\$ 122 \mathrm{j} \mathrm{Um}$ wandlungsgesetz, respectively). 
division and the cross-border conversion. Thereby the EMCA may serve as an inspiration for legislators inside and outside the European Union and as a benchmark for future discussions on European company law. 